\title{
Penerapan Fuzzy C-Means Untuk Penentuan Besar Uang Kuliah Tunggal Mahasiswa Baru
}

\author{
Ariyady Kurniawan Muchsin ${ }^{1}$, Made Sudarma ${ }^{2}$ \\ Magister Teknik Elektro, Universitas Udayana \\ Jalan P.B. Sudirman, Bali, Indonesia \\ 1ariyadykurniawan@gmail.com \\ 2msudarma@unud.ac.id
}

\begin{abstract}
Abstrak
Sesuai dengan amanat UUD 1945 pasal 31 tentang pendidikan pemerintah telah mengeluarkan berbagai kebijakan untuk mewujudkan biaya pendidikan yang semakin murah dan terjangkau oleh semua kalangan masyarakat, salah satunya ialah dengan sistem UKT (Uang Kuliah Tunggal) yaitu merupakan sebagian Biaya Kuliah Tunggal (BKT) yang ditanggungkan kepada setiap mahasiswa berdasarkan kemampuan ekonominya. Mekanisme penentuan golongan UKT saat ini masih dilakukan secara manual oleh Universitas Udayana yang mengakibatkan nilai keadilan bagi calon mahasiswa baru terhadap kemampuan ekonomi mereka masih dirasakan kurang. Oleh karena itu dibutuhkan suatu mekanisme pengisian dan penentuan UKT yang dapat dilakukan secara online, sehingga dapat meningkatkan efisiensi dan efektivitas. Solusi selanjutnya yang dapat dilakukan ialah dengan menggunakan teknik klasifikasi menggunakan Fuzzy C-Means (FCM) dan Index Xie Beni untuk menentukan cluster optimum dalam proses penentuan golongan UKT sehingga dapat memenuhi nilai keadilan bagi calon mahasiswa baru.
\end{abstract}

Kata kunci: Uang kuliah tunggal, UKT, Fuzzy C-means, FCM, Index Xie Beni.

\begin{abstract}
In accordance with the mandate of the 1945 Constitution article 31 concerning the education authorities have issued various policies to realize the cost of education is getting cheaper and affordable to all people, one of which is the system UKT (Tuition Single) which is partially Tuition Single (BKT) which were passed to each student based on their economic capabilities. UKT grouping mechanism is still done manually by Udayana University which resulted in the value of equity for prospective new students to their economic capacity is still lacking. Therefore, it needs a mechanism for charging and determination UKT which can be done online, so as to improve efficiency and effectiveness. The next solution that can be done is by using classification techniques using Fuzzy C-Means (FCM) and Beni Xie Index to determine the optimum clusters in the process of determining the type UKT so as to meet the values of justice for prospective new students.
\end{abstract}

Keywords: Tuition Single, UKT, Fuzzy C-Means, FCM, Index Xie Beni.

\section{Pendahuluan}

Biaya pendidikan saat ini khususnya di perguruan tinggi dirasakan semakin mahal dari tahun ke tahun. nominal uang pangkal yang besar terasa sangat memberatkan ketika harus dibayarkan sewaktu menjadi mahasiswa baru, hal ini juga akan memberikan dampak negatif bagi mahasiswa seperti adanya fakultas atau jurusan yang terkesan eksklusive.

Sistem UKT (Uang Kuliah Tunggal) yaitu merupakan sebagian Biaya Kuliah Tunggal (BKT) yang ditanggungkan kepada setiap mahasiswa berdasarkan kemampuan ekonominya. Biaya 
kuliah Tunggal merupakan seluruh biaya operasional per mahasiswa per semester pada program studi di perguruan tinggi negeri dan UKT itu ditetapkan berdasarkan BKT dikurangi dengan biaya yang ditanggung oleh pemerintah. yang akan dilaksanakan oleh perguruan tinggi negeri, kebijakan ini bertujuan untuk meringankan beban uang kuliah yang harus dibayarkan oleh mahasiswa dari awal masuk perkuliahan hingga lulus nanti. Tata cara penggunaan dan penetapan nominal UKT itu sendiri telah diatur oleh undang-undang sesuai dengan kebutuhan operasional universitas negeri yang bersangkutan dalam menjalankan kegiatan belajar mengajar, undang-undang tersebut diantaranya Undang-Undang No.12 Tahun 2012 [1] tentang pendidikan tinggi terkait Bantuan Operasional Perguruan Tinggi Negeri, Biaya Kuliah Tunggal, dan Uang Kuliah Tunggal.

Metode Fuzzy C-means Clustering (FCM) adalah suatu teknik pengclusteran data yang mana keberadaan tiap-tiap titik data dalam suatu cluster ditentukan oleh derajat keanggotaan. FCM menggunakan model pengelompokan fuzzy dengan indeks kekaburan menggunakan Euclidean Distance sehingga data dapat menjadi anggota dari semua kelas atau cluster yang terbentuk dengan derajat keanggotaan yang berbeda antara 0 hingga 1 [2]. Metode FCM sudah banyak digunakan dalam beberapa penelitian sebelumnya diantaranya ialah cluster rawan pangan di Kabupaten Cirebon [3] penelitian ini bertujuan indeks pembangunan manusia di kawasan Indonesia Timur tahun 2012 [4], segmentasi pelanggan PLN menggunakan fuzzy klustering short time series [5], sistem pemilihan perumahan dengan metode kombinasi fuzzy c-means clustering dan simple additive weighting [6], penerapan metode hybrid fuzzy c-means dan particle swarm optimization (FCM - PSO) untuk segmentasi citra geografis [7], pemanfaatan algoritma FCM dalam pengelompokan kinerja akademik mahasiswa [8].

\section{Metodologi Penelitian}

\subsection{Identifikasi Masalah}

Masalah-masalah yang dihadapi dalam pembuatan sistem penentuan UKT ini adalah :

a. Banyaknya inputan mahasiswa yang bervariasi.

b. Banyaknya kriteria penilaian yang menentukan golongan UKT.

c. Periode penerimaan mahasiswa baru yang berbeda.

\subsection{Jenis dan Sumber Data}

Sumber data yang dari penelitian ini adalah isian form calon mahasiswa baru berjumlah 57 pertanyaan yang telah diinputkan secara online melalui sistem yang telah ada, data itu sendiri tersimpan didalam server database yang dikelola oleh Unit Sumber Daya Informasi Universitas Udayana Bukit Jimbaran Bali. Dari 57 pertanyaan tersebut penelitian ini akan mengambil 7 poin utama yang telah dirasa sangat cukup bagi pihak univeristas untuk menggambarkan kemampuan ekonomi dari keluarga calon mahasiswa baru di Universitas Udayana, 7 poin tersebut ialah sebagai berikut :
a. Nilai Jual Objek Pajak (NJOP) tanah (Rp)
b. Rata-rata rekening air perbulan $(R p)$ dalam 3 bulan terakhir
c. Rata-rata rekening listrik perbulan (Rp) dalam 3 bulan terakhir
d. Nilai total saat ini dari mobil dalam keluarga (Rp).
e. Nilai total saat ini dari sepeda motor dalam keluarga (Rp).
f. Jumlah tanggungan orang tua berdasarkan KK (orang)
g. Total penghasilan keluarga (Ayah + lbu + Pendapatan Lainnya) (Rp).

\section{Kajian Pustaka}

\subsection{Uang Kuliah Tunggal (UKT)}

Hakekat dari UKT adalah guna meringankan beban mahasiswa terhadap pembiayaan pendidikan, oleh karena itu pemerintah melalui Menteri Pendidikan dan Kebudayaan (Mendikbud) pada tanggal 23 Mei 2013 telah mengeluarkan ketetapan mengenai besarnya Biaya Kuliah Tunggal (BKT) dan Uang Kuliah Tunggal (UKT) pada Perguruan Tinggi Negeri (PTN) di lingkungan Kementerian Pendidikan dan Kebudayaan (Kemdikbud). Ketentuan itu 
tertuang dalam Peraturan Menteri Pendidikan dan Kebudayaan (Permendikbud) No. 55 Tahun 2013 tertanggal 23 Mei 2013 [9].

\subsection{Sistem Pendukung Keputusan}

Sistem Pendukung Keputusan merupakan Sistem berbasis komputer yang interaktif yang membantu pengambil keputusan dengan memanfaatkan data dan model untuk menyelesaikan masalah-masalah yang tak terstruktur [10]. Ada yang mendefinisikan bahwa sistem pendukung keputusan merupakan suatu pendekatan untuk mendukung pengambilan keputusan. Sistem pendukung keputusan menggunakan data, memberikan antarmuka pengguna yang mudah, dan dapat menggabungkan pemikiran pengambil keputusan [11].

\subsection{Fuzzy C-Means}

Konsep dasar FCM, pertama kali adalah menentukan pusat cluster, yang akan menandai lokasi rata-rata untuk tiap cluster. Pada kondisi awal, pusat cluster masih belum akurat. Tiap-tiap titik data memiliki derajat keanggotaan untuk tiap cluster yang terbentuk. Dengan cara memperbaiki pusat cluster dan derajat keanggotaan tiap-tiap titik data secara berulang, maka akan dapat dilihat bahwa pusat cluster akan bergeser menuju lokasi yang tepat. Perulangan ini didasarkan pada minimasi fungsi objektif yang menggambarkan jarak dari titik data yang diberikan ke pusat cluster yang terbobot oleh derajat keanggotaan titik data tersebut. Algoritma FCM adalah sebagai berikut [12]:

a. Masukkan data yang akan dicluster ke dalam sebuah matriks $\mathrm{X}$, dimana matriks berukuran $\mathrm{m} \times \mathrm{n}$, dengan $\mathrm{m}$ adalah jumlah data yang akan dicluster dan $\mathrm{n}$ adalah atribut setiap data. Contoh $\mathrm{Xij}=$ data ke-i $(\mathrm{i}=1,2, \ldots \mathrm{m})$, atribut ke-j $(\mathrm{j}=1,2, \ldots \mathrm{n})$.

b. Tentukan

1. Jumlah cluster $=\mathrm{c}$;

2. Pangkat/pembobot $=\mathbf{w}$;

3. Maksimum iterasi $=$ Makslter;

4. Error yang diharapkan $=\xi$;

5. Fungsi Objektif awal $=\mathrm{PO}=0$;

6. Iterasi awal $=\mathrm{t}=1$;

c. Bangkitkan bilangan acak $\mu$ ik (dengan $\mathrm{i}=1,2, \ldots \mathrm{m}$ dan $\mathrm{k}=1,2, \ldots \mathrm{c}$ ) sebagai elemen matriks

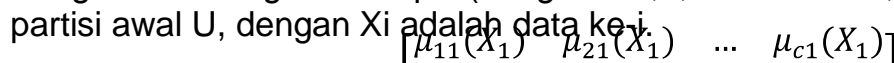

$$
U=\left[\begin{array}{cccc}
\mu_{11}\left(X_{1}\right) & \mu_{21}\left(X_{1}\right) & \ldots & \mu_{c 1}\left(X_{1}\right) \\
\mu_{12}\left(X_{2}\right) & \mu_{21}\left(X_{1}\right) & \ldots & \mu_{c 2}\left(X_{2}\right) \\
\vdots & \vdots & & \vdots \\
\mu_{1 i}\left(X_{i}\right) & \mu_{21}\left(X_{i}\right) & \ldots & \mu_{c i}\left(X_{i}\right)
\end{array}\right]
$$

Dengan jumlah setiap nilai elemen kolom dalam satu baris adalah 1 (satu).

$$
\sum_{i=1}^{c} \mu_{c i}=1
$$

d. Hitung pusat cluster ke-k : Vkj , dengan $\mathrm{k}=1,2, \ldots, \mathrm{c}$ dan $\mathrm{j}=1,2, \ldots, \mathrm{n}$

$$
V_{k j}=\frac{\sum_{i=1}^{m}\left(\mu_{i k}\right)^{w *} X_{i j}}{\sum_{i=1}^{m}\left(\mu_{i k}\right)^{w}}
$$

e. Hitung fungsi objektif pada iterasi ke-t, $\mathrm{Pt}$ :

$$
P_{t}=\sum_{i=k}^{m} \sum_{k=i}^{c}\left(\left[\sum_{j=1}^{n}\left(X_{i j}-V_{k j}\right)^{2}\right]\left(\mu_{i k}\right)^{w}\right)
$$

f. Hitung perubahan derajat keanggotaan setiap data pada setiap cluster (memperbaiki matriks partisi U ) dengan : 


$$
\mu_{i k}=\frac{\left[\sum_{j=1}^{n}\left(X_{i j}-V_{k j}\right)^{2}\right]^{\frac{-1}{w-1}}}{\sum_{k=1}^{c}\left[\sum_{j=1}^{n}\left(X_{i j}-V_{k j}\right)^{2}\right]^{\frac{-1}{w-1}}}
$$

g. Cek kondisi berhenti :

- Jika : ( $|\mathrm{Pt}-\mathrm{Pt}-1|<\xi)$ atau ( $\mathrm{t}>$ Makslter) maka berhenti ;

- Jika tidak : $t=t+1$, ulangi langkah 4

\subsection{Index XB (Xie-Beni)}

Indeks XB ditemukan oleh Xie dan Beni yang pertama kali dikemukakan pada tahun 1991. Ukuran kevalidan cluster merupakan proses evaluasi hasil clustering untuk menentukan cluster mana yang terbaik. Ada dua kriteria dalam mengukur kevalidan suatu cluster, yaitu :

a. Compactness, yaitu ukuran kedekatan antar anggota pada tiap cluster.

b. Separation, yaitu ukuran keterpisahan antar cluster satu dengan cluster yang lainnya. Rumus kevalidan suatu cluster atau indeks Xie-Beni (XB) [7] yaitu:

$$
X B=\frac{\sum_{i=1}^{c} \sum_{j=1}^{n} \mu_{i k}{ }^{w *}\left\|V_{i^{-}} X_{j}\right\|^{2}}{n^{*} \min _{i, i}\left\|V_{i^{-}} V_{i}\right\|^{2}}
$$

Dengan $\mathrm{c}=$ banyak klaster, $\mathrm{n}=$ banyak objek yang dikelompokkan, $\mu_{i k}=$ derajat keanggotaan fuzzy, $\mathrm{W}=$ pangkat pembobot (fuzzifier), $n^{*} m \mathrm{~min}_{i, i}\left\|V_{i}-V_{i}\right\|^{2}$ adalah jarak minimum antara pusat klaster $v_{i}$ dan $v_{j}$.

\section{Hasil dan Pembahasan}

\subsection{Fuzzy C-Means}

Adapun proses dalam penggunaan metode FCM dalam penetlitian ini adalah sebagai berikut :

Langkah 1

Masukkan data yang akan di-cluster kedalam matriks $\mathrm{X}$ dengan $\mathrm{i}=7$ yang merupakan banyaknya sampel yang diambil secara acak berdasarkan satu periode penerimaan mahasiswa baru dalam satu jurusan di Universitas Udayana dan $\mathrm{j}=7$ yang merupakan nilai dari aspek yang telah didefinisikan sebelumnya, nilai nominal rupiah dikalikan dengan $10^{-6}$, sehingga menjadi matriks berikut ini.

$$
X=\left[\begin{array}{ccccccc}
20 & 0,04875 & 0,065254 & 0 & 5 & 3 & 3 \\
0,394 & 0 & 0,1 & 50 & 25 & 5 & 4,6 \\
2 & 0,0305 & 0,051349 & 70 & 10 & 2 & 4,5884 \\
2.43 & 0,035 & 0,035 & 0 & 12 & 2 & 5 \\
20 & 0,0255 & 0,02 & 0 & 4 & 4 & 1,5 \\
0.2 & 0,05 & 0,1 & 0 & 8 & 1 & 3,5 \\
0.355 & 0.1 & 0.25 & 0 & 15 & 1 & 5
\end{array}\right]
$$

Langkah 2

Inisialisasi parameter yang akan digunakan :

a. Banyaknya cluster yang diinginkan $\rightarrow \mathrm{c}=3$

b. Pangkat (pembobot) $\rightarrow \mathrm{w}=2$, angka 2 merupakan nilai perpangkatan yang paling optimal dan paling sering dipakai [5].

c. Maksimum Iterasi $\rightarrow$ maxlter $=3$

d. Error terkecil yang diharapkan $\rightarrow \xi=0,01$

e. Fungsi Objektif awal $\rightarrow \mathrm{PO}=0$

f. Iterasi awal $\rightarrow \mathrm{t}=1$; 
Langkah 3

Bangkitkan matriks $\mathrm{U}$ dengan komponen $\mu_{\mathrm{ik}}, \mathrm{i}=7 ; \mathrm{k}=3$, nilai $\mu_{\mathrm{ik}}$ ditentukan secara acak dengan syarat jumlah nilai elemen matriks dari kolom dalam setiap baris harus sama dengan 1 , sehingga di dapat matriks $U$ sebagai berikut.

$$
U=\left[\begin{array}{lll}
0,30 & 0,30 & 0,40 \\
0,50 & 0,30 & 0,20 \\
0,40 & 0,40 & 0,20 \\
0,50 & 0,30 & 0,20 \\
0,40 & 0,20 & 0,40 \\
0,10 & 0,80 & 0,10 \\
0,25 & 0,25 & 0,50
\end{array}\right]
$$

Langkah 4

Hitung Pusat Cluster dengan menggunakan persamaan 3 maka akan didapatkan pusat cluster seperti tabel 1.

Tabel 1. Pusat cluster iterasi-1

\begin{tabular}{crrrrrrc}
\hline Vkj & \multicolumn{1}{c}{1} & \multicolumn{1}{c}{2} & \multicolumn{1}{c}{3} & \multicolumn{1}{c}{4} & \multicolumn{1}{c}{5} & \multicolumn{1}{c}{6} & \multicolumn{1}{c}{7} \\
\hline 1 & 35.787 & 0.029 & 0.069 & 24.122 & 13.188 & 4.125 & 2.918 \\
2 & 2.835 & 0.044 & 0.091 & 13.390 & 9.891 & 2.083 & 3.476 \\
3 & 9.548 & 0.057 & 0.120 & 6.857 & 10.214 & 2.714 & 3.418 \\
\hline
\end{tabular}

Langkah 5

Hitung fungsi objektif $(P)$ dengan menggunakan persamaan 4 maka akan didapatkan fungsi objektif (P1).

$$
\mathrm{P} 1=4274,037
$$

Langkah 6

Perbaharui matriks $U$ dengan menggunakan persamaan 5 maka akan didapatkan matriks partisi $U$ yang baru sebagai berikut :

$$
U=\left[\begin{array}{lll}
0,130 & 0,234 & 0,636 \\
0,307 & 0,400 & 0,292 \\
0,354 & 0,360 & 0,286 \\
0,043 & 0,350 & 0,607 \\
0,136 & 0,241 & 0,623 \\
0,041 & 0,409 & 0,549 \\
0,047 & 0,406 & 0,547
\end{array}\right]
$$

Langkah 7

Cek kondisi berhenti :

a. Apakah $1>3$ ? <<salah >>

b. Apakah $|4274,037-0|<0.01 ?<<$ salah $>>$ Maka ulangi langkah 3.

Setelah sampai pada kondisi berhenti tersebut maka didapatkan pusat cluster seperti tabel 2.Dengan matriks $U$ sebagai berikut : 


$$
U=\left[\begin{array}{lll}
0,022 & 0,353 & 0,625 \\
0,898 & 0,058 & 0,044 \\
0,925 & 0,041 & 0,034 \\
0,010 & 0,425 & 0,565 \\
0,023 & 0,354 & 0,623 \\
0,012 & 0,445 & 0,543 \\
0.016 & 0.506 & 0.477
\end{array}\right]
$$

Tabel 2. Pusat cluster iterasi-3

\begin{tabular}{ccccrrcc}
\hline Vkj & 1 & 2 & 3 & \multicolumn{1}{c}{4} & \multicolumn{1}{c}{5} & 6 & 7 \\
\hline 1 & 1.209 & 0.015 & 0.077 & 59.207 & 17.821 & 3.571 & 4.585 \\
2 & 6.709 & 0.054 & 0.112 & 6.688 & 10.310 & 2.686 & 3.243 \\
3 & 8.716 & 0.050 & 0.088 & 0.147 & 8.687 & 3.100 & 2.608 \\
\hline
\end{tabular}

Tabel 3 menunjukkan hasil akhir cluster berdasarkan nilai keanggotaannya pada iterasi terakhir.

Tabel 3. Hasil clustering fuzzy c-means

\begin{tabular}{crrrr}
\hline \multirow{2}{*}{ Data } & \multicolumn{3}{c}{ Derajat Keanggotaan } & \multirow{2}{*}{ cluster } \\
& cluster 1 & cluster 2 & cluster 3 & \\
\hline Mahasiswa 1 & 0.022 & 0.353 & 0.625 & 3 \\
Mahasiswa 2 & 0.898 & 0.058 & 0.044 & 1 \\
Mahasiswa 3 & 0.925 & 0.041 & 0.034 & 1 \\
Mahasiswa 4 & 0.010 & 0.425 & 0.565 & 3 \\
Mahasiswa 5 & 0.023 & 0.354 & 0.623 & 3 \\
Mahasiswa 6 & 0.012 & 0.445 & 0.543 & 3 \\
Mahasiswa 7 & 0.016 & 0.506 & 0.477 & 2 \\
\hline
\end{tabular}

\subsection{Index XB (Xie-Beni)}

Dengan menggunakan persamaan 6 maka kita dapat menentukan nilai dari index xie beni, tujuannya ialah agar dapat ditentukan golongan UKT mahasiswa dari yang terbesar sampai yang terkecil dengan melihat nilai dari index xie beni dari tiap cluster. Hasilnya didapatkan nilai index XB untuk setiap cluster seperti pada tabel 4.

Tabel 4. Hasil index xie-beni

\begin{tabular}{llll}
\hline Cluster & Compactness & Separation & Index XB \\
\hline c1 & 272.44 & 0.003877648 & 10037 \\
c2 & 141.845 & 0.000443572 & 45683 \\
c3 & 195.575 & 0.000863477 & 32357 \\
\hline
\end{tabular}

\subsection{Hasil Perhitungan}

Dari hasil perhitungan diatas akan didapatkan suatu hasil diamana cluster 1 akan digolongkan ke dalam UKT 2, cluster 2 akan digolongkan ke dalam UKT 1 dan cluster 3 akan digolongkan ke dalam UKT 3, sehingga mendapatkan hasil clustering seperti pada tabel 5.

Tabel 5. Hasil pembagian UKT

\begin{tabular}{|c|c|c|c|c|c|}
\hline Data & $\begin{array}{l}\text { Derajat Ke } \\
\text { cluster } 1\end{array}$ & $\begin{array}{l}\text { nggotaan } \\
\text { cluster } 2\end{array}$ & cluster 3 & cluster & UKT \\
\hline Mahasiswa 1 & 0.035 & 0.462 & 0.504 & 3 & UKT 2 \\
\hline Mahasiswa 2 & 0.912 & 0.035 & 0.053 & 1 & UKT 3 \\
\hline Mahasiswa 3 & 0.891 & 0.047 & 0.061 & 1 & UKT 3 \\
\hline Mahasiswa 4 & 0.020 & 0.520 & 0.460 & 2 & UKT 1 \\
\hline Mahasiswa 5 & 0.035 & 0.486 & 0.479 & 2 & UKT 1 \\
\hline Mahasiswa 6 & 0.016 & 0.680 & 0.304 & 2 & UKT 1 \\
\hline Mahasiswa 7 & 0.032 & 0.432 & 0.536 & 3 & UKT 2 \\
\hline
\end{tabular}




\subsection{Desain ERD (Entity Relatonship Diagram)}

ERD (Entity Relatonship Diagram) merupakan tahap menententukan relasi antar entitas sehingga informasi yang diperoleh menjadi terelasi dengan baik, hasil akhir dari proses ini ialah berupa tabel fisik yang telah terelasi antara satu tabel dengan tabel yang lainnya.

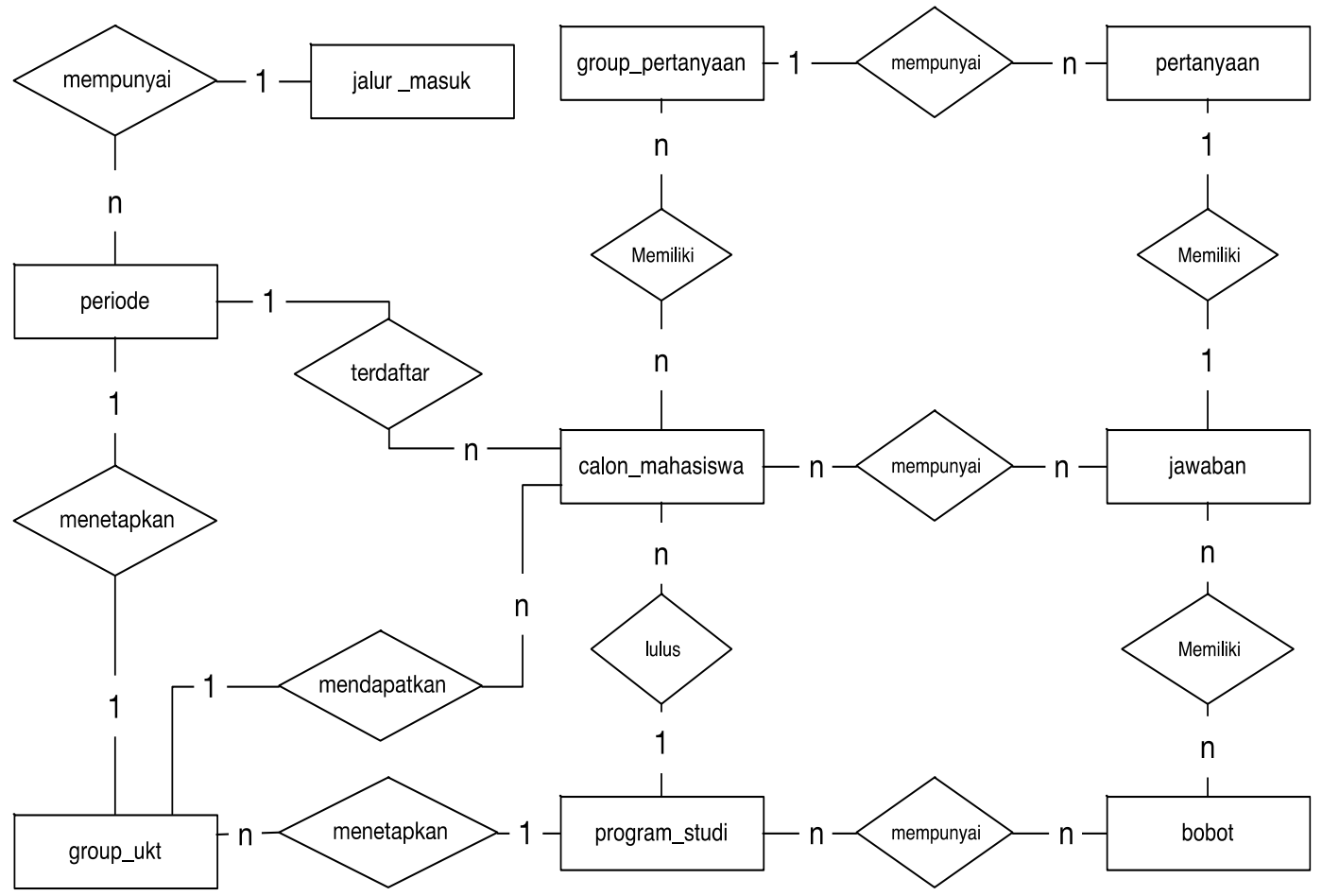

Gambar 1. ERD (Entity Relatonship Diagram) sistem UKT

\subsection{Implementasi SIstem}

Sistem akan dibangun berbasis online menggunakan teknologi web menghasilkan tampilan seperti pada Gambar 2 yang merupakan tampilan awal dari web UKT yang dibangun. Terdapat beberapa input text yaitu username dan password serta combo box periode penerimaan mahasiswa baru.

Gambar 3 merupakan tampilan form isian yang akan diinput oleh calon mahasiswa baru, terdiri dari beberapa group dan masing-masing group terdiri dari beberapa pertanyaan. Gambar 4 merupakan tampilan dashboard admin terdapat beberapa menu yaitu diantaranya lihat UKT untuk melihat isian UKT calon mahasiswa baru, Group UKT untuk melakukan setting nominal UKT tiap jurusan dan persentase masing-masing golongan UKT, menu hitung UKT untuk melakukan proses perhitungan dengan metode fuzzy c-means, dan menu assign untuk melakukan import data calon mahasiswa baru. Gambar 5 merupakan tampilan hasil perhitungan yang menampilkan golongan UKT calon mahasiswa baru. 


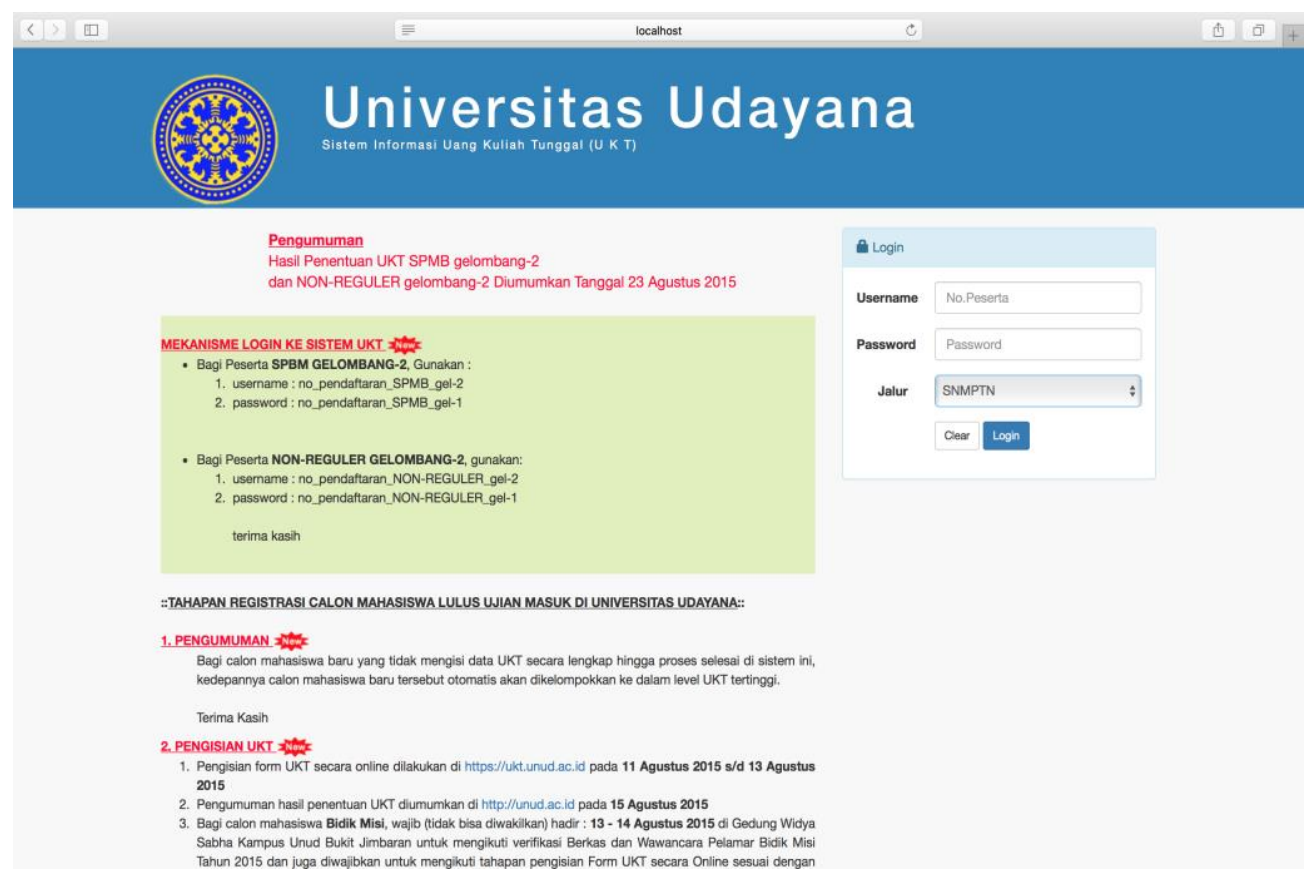

Gambar 2. Tampilan awal web UKT

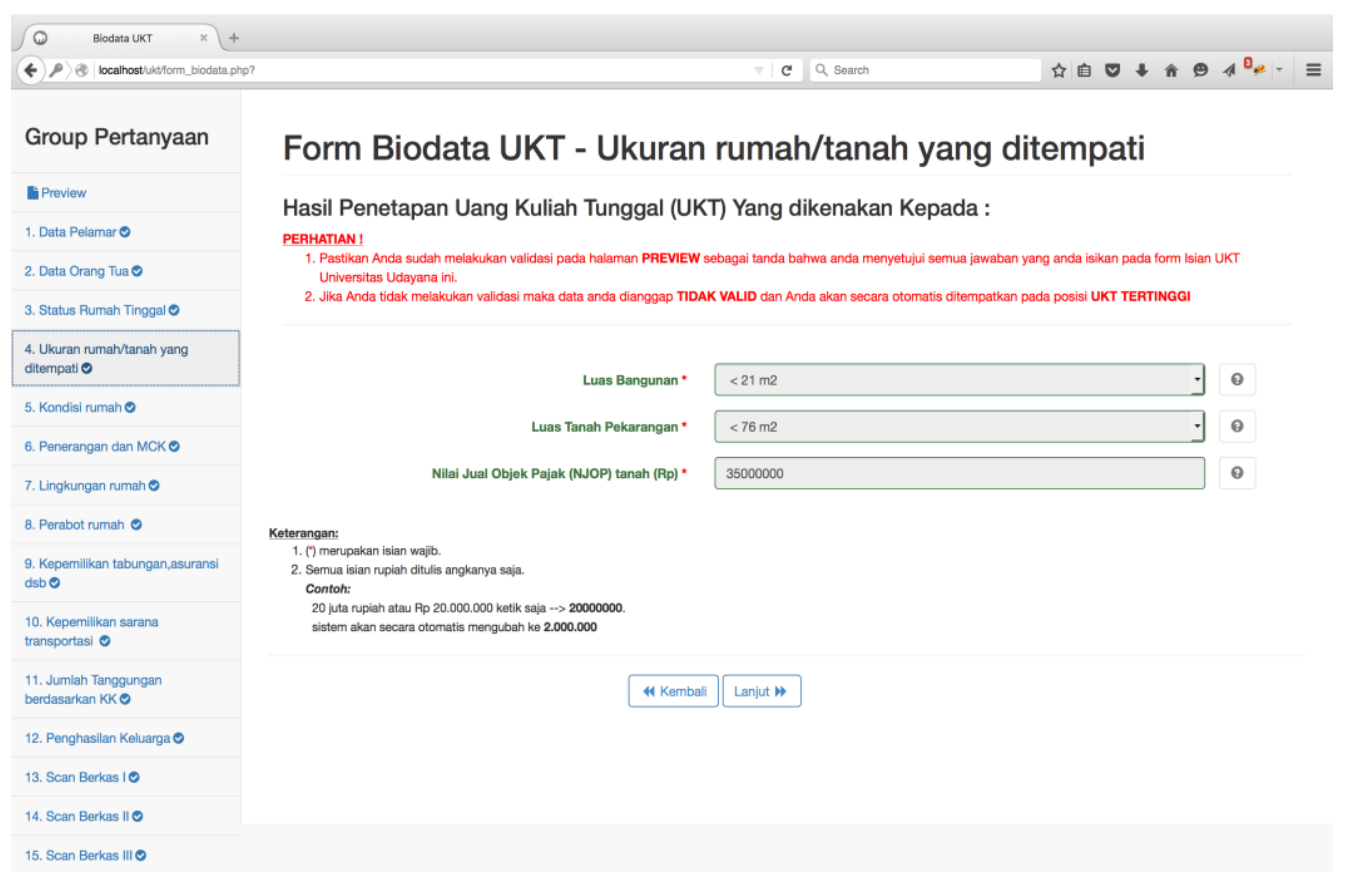

Gambar 3. Tampilan isian UKT 


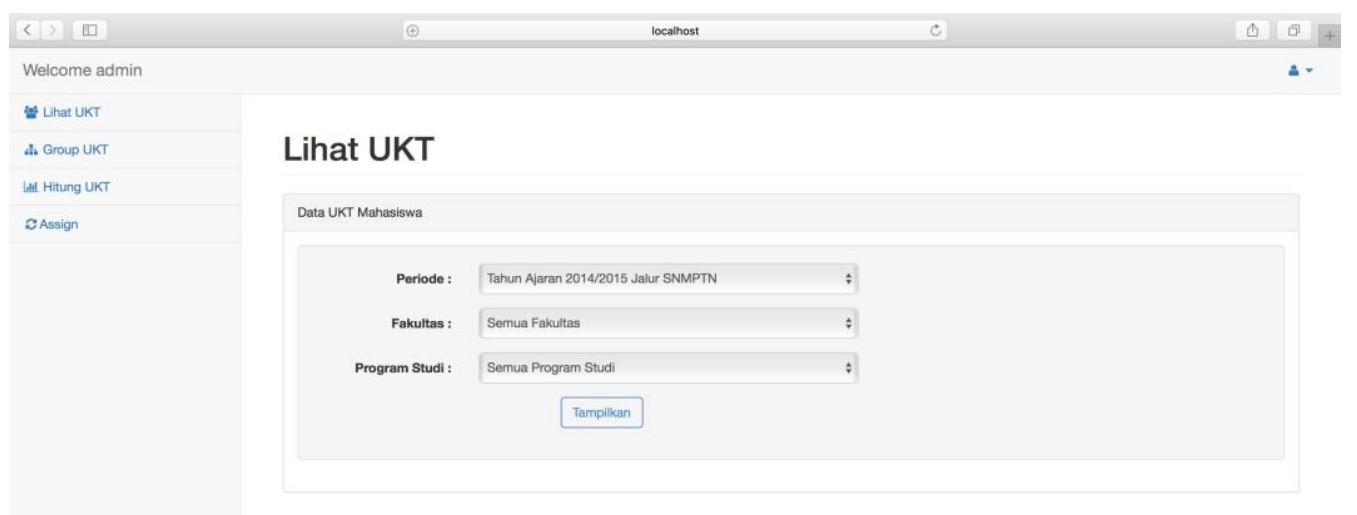

Gambar 4. Dashboard admin

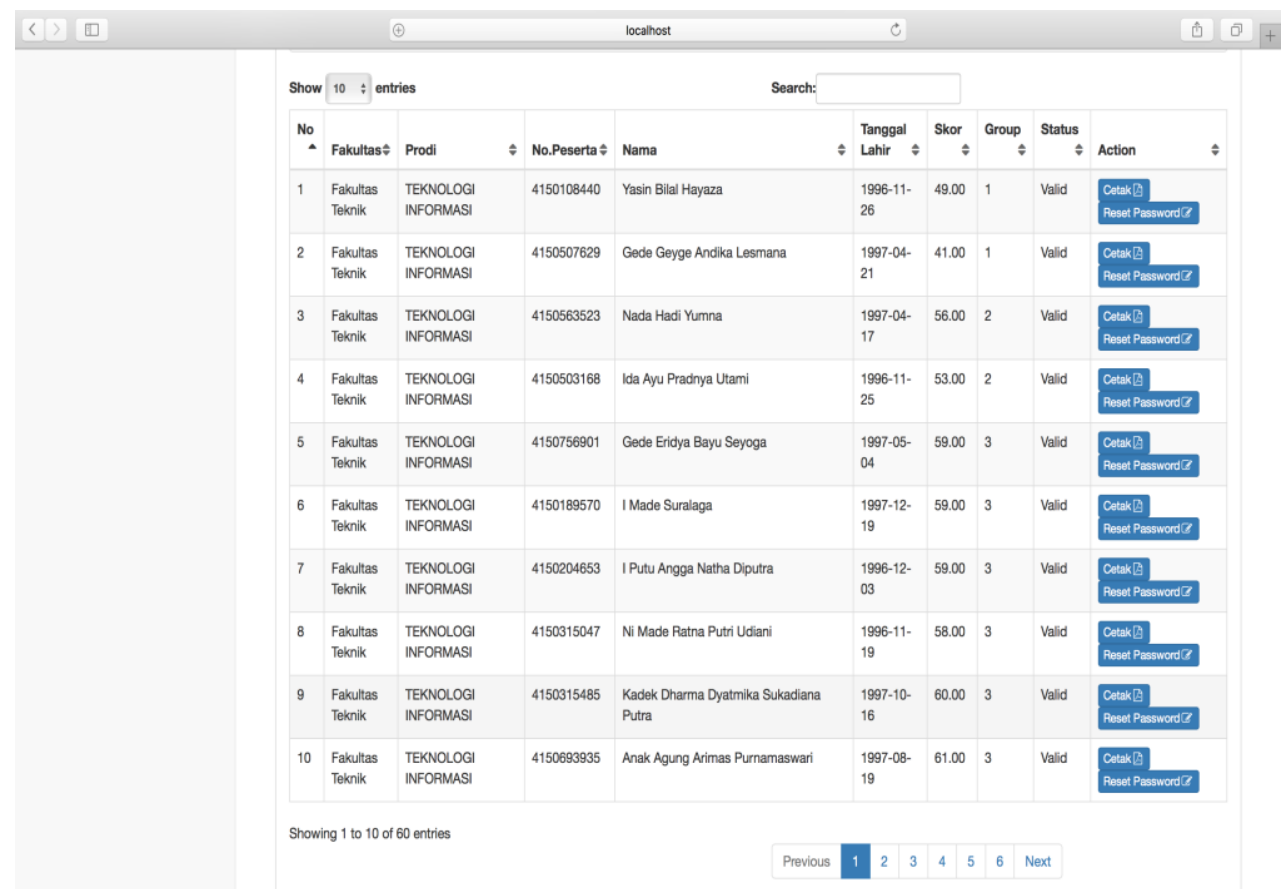

Gambar 5. Hasil pembagian golongan UKT

\section{Kesimpulan}

Berdasarkan hasil dan pembahasan dapat disimpulkan bahwa 7 point yang menggambarkan kondisi perekonomian keluarga calon mahasiswa baru dan dengan teknik clustering FCM dan Index Xie Beni data tersebut dapat diolah menjadi golongan UKT sehingga dapat membantu 
pihak universitas untuk memenuhi rasa keadilan dalam menentukan golongan UKT bagi calon mahasiswa baru.

\section{Daftar Pustaka}

[1] Republik Indonesia, Undang-Undang No.12. 2012.

[2] E. T. Luthfi, "Fuzzy C-Means untuk Clustering Data (Studi Kasus: Data Performance Mengajar Dosen )," in Prosiding Seminar Nasional Teknologi, pp. 1-7.

[3] Harliana and Azhari, "Penerapan FCM dan TSK Untuk Penentuan Cluster Rawan Pangan di Kabupaten Cirebon," IJCCS, vol. 6, no. 2, pp. 1-10, 2012.

[4] R. Syaiful and R. . F. Hakim, "Metode K-Means Cluster Dan Fuzzy C-Means Cluster (Studi Kasus: Indeks Pembangunan Manusia di Kawasan Indonesia Timur tahun 2012)," in Prosiding Seminar Nasional Matematika dan Pendidikan Matematika UMS, 2015.

[5] M. T. Jatipaningrum, "Segmentasi Pelanggan PLN Menggunakan Fuzzy Klustering Short Time Series," in Prosiding Seminar Nasional Aplikasi Sains \& Teknologi (SNAST), 2014.

[6] T. Sandhika Jaya, K. Adib, and B. Noranitab, "Sistem Pemilihan Perumahan dengan Metode Kombinasi Fuzzy C-Means Clustering dan Simple Additive Weighting," Jurnal Sistem Informasi Bisnis, 2011.

[7] A. Naba, "Penerapan Metode Hybrid Fuzzy C-Means dan Particle Swarm Optimization (FCM - PSO) untuk Segmentasi Citra Geografis," J. EECCIS, vol. 8, no. 1, Jun. 2014.

[8] R. Aidina, "Pemanfaatan Algoritma FCM Dalam Pengelompokan Kinerja Akademik Mahasiswa," in Konferensi Nasional Sistem \& Informatika 2015, 2015, pp. 431-436.

[9] M. P. dan K. Republik Indonesia, "Peraturan Menteri Pendidikan dan Kebudayaan (Permendikbud) No. 55." Republik Indonesia, 2013.

[10] H. Rohayani, "Analisis Sistem Pendukung Keputusan Dalam Memilih Program Studi Menggunakan Metode Logika Fuzzy," Jurnal Sistem Informasi, vol. 5, no. 1, pp. 530539, 20113.

[11] E. Turban, J. E. Aronson, and T.-P. Liang, Decision Support and Intelegent System, 7th ed. Prentice-Hall, 2007.

[12] S. Kusumadewi and H. Purnomo, Aplikasi Logika Fuzzy untuk Pendukung Keputusan. Yogyakarta: Graha IImu, 2010. 